学会賞受賞論文

|IIIIIIIIIIIIIIIIIIIIIIIIIIIIIII

（業績賞・技術）

\title{
殺虫剂「フロニカミド」の研究開発
}

\author{
森田雅之更, 米田哲 夫 $^{2}$, 秋吉 信 行 $^{1}$ \\ 1 石原産業株式会社バイオサイエンス営業本部 \\ 2 石原産業株式会社中央研究所
}

（2014年6月 10 日受理）

\section{Research and development of a novel insecticide, flonicamid}

\author{
Masayuki Morita, ${ }^{1}$ Tetsuo YonedA ${ }^{2}$ and Nobuyuki AkıYoshi ${ }^{1}$ \\ ${ }^{1}$ Biosciences Sales \& Marketing, Ishihara Sangyo Kaisha, Ltd., \\ 1-3-15 Edobori, Nishi-ku, Osaka 550-0002, Japan \\ ${ }^{2}$ Central Research Institute, Ishihara Sangyo Kaisha, Ltd., \\ 2-3-1 Nishi-shibukawa, Kusatsu, Shiga 525-0025, Japan
}

Keywords: flonicamid, insecticide, aphid, sucking insect, IPM.

\section{は じめに}

フロニカミド1 (Flonicamid, Fig. 1) は, 石原産業(株)が 創製した構造的にも作用機作的にも独創性の高い殺虫剂であ り，アブラムシ類を主とした吸汁性害虫に殺虫スペクトルを 有する一方，天敵や有用昆虫に対して影響が少ない選択的な 殺虫剤である，我々はトリフルオロメチルピリジンを有する 化合物の生物活性に関する一連の研究を通じて，4-(トリフ ルオロメチル）二コチン酸アミド誘導体がアブラムシへ特異 的に殺虫活性を示すことを見出し，これを端緒に，その後の 構造変換による最適化研究を経て本剤の完成に至った ${ }^{1-3)}$.

フロニカミドは, アブラムシの吸汁行動を速効的, かつ強 力に阻害し，その作用はアブラムシが死亡するまで継続する ことから, 本剂のアブラムシに対する殺虫作用は餓死による ものと考えられる．既存剤に抵抗性を獲得した種にも有効で 抵抗性管理に貢献でき, さらに, 天敵や訪花昆虫等の標的外

\footnotetext{
* = 550-0002 大阪市西区江戸堀 1-3-15

E-mail: m-morita@iskweb.co.jp

(c) 日本農薬学会
}

生物に影響が少ないことから, IPM（総合的病害虫管理）に 適合した化学農薬である ${ }^{4,5)}$. アブラムシ類以外の害虫に対 しては種により活性差はあるが, 茶などのヨコバイ類, 棉の Lygus spp.などの重要害虫に対して固場で高い防除効果があ り，国内外で実用化されている.

本剂は日本では, 商品名ウララDFとして2006年10月に 農薬登録され, 販売を開始した. 海外での開発も並行して 進められ，2003年の米国非食用分野での登録認可を皮切り に，2005年に英国，フランス，オランダ等のEU諸国，米国 (棉・食用分野), ブラジル, コロンビア, 韓国で農薬登録を 取得した。2014年1月末までに 41 か国で農薬登録され, 各

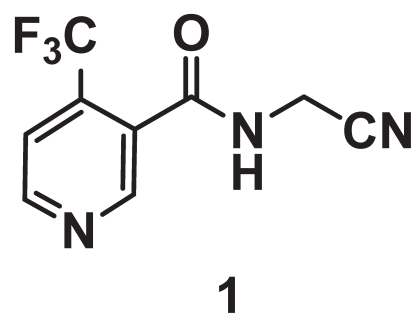

Fig. 1. Chemical structure of flonicamid. 


$$
\mathrm{F}_{3} \mathrm{C}
$$<smiles>CCCCOC(=O)C(C)Oc1ccc(Oc2ccc(C)cn2)cc1</smiles>

fluazifop-butyl

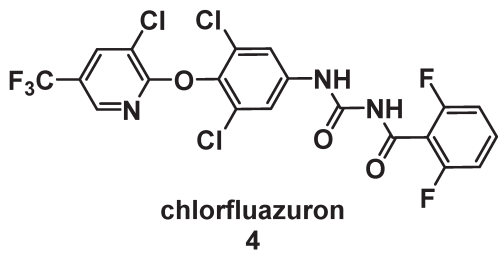

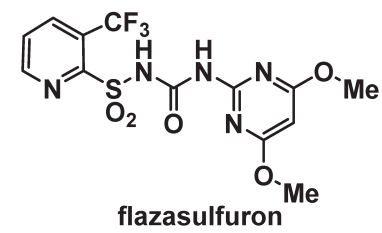

3

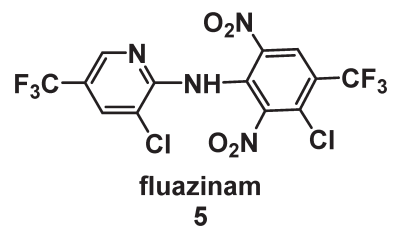

Fig. 2. $\mathrm{CF}_{3}$-pyridine substituted agrochemicals developed by Ishihara Sangyo Kaisha.

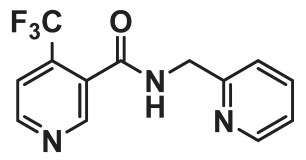

Myzus persicae

LC $_{90} 12.5$ ppm

6

Fig. 3. Insecticidal effect of lead compound.

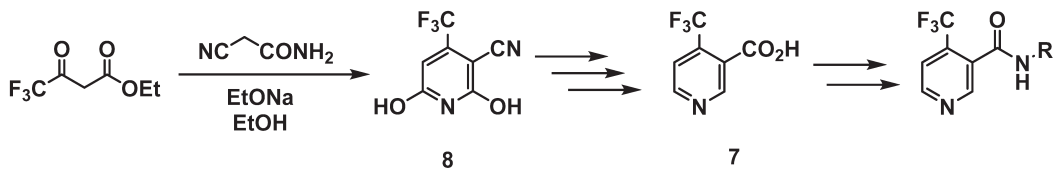

Fig. 4. Synthesis of 4-(trifluoromethyl)nicotinamide.

国の作物保護に貢献している。本稿では，フロニカミドの創 製の経緯, 生物活性の特徴, 安全性について概要を述べる。

\section{1. フロニカミドの創製の経緯}

\section{1. リード化合物の発見}

当社では, 置換基としてトリフルオロメチル基をもつピ リジン $\left(\mathrm{CF}_{3}\right.$-ピリジン）誘導体が示す生理活性に興味をも ち, 精力的に研究を継続してきた。一連の研究からフルアジ ホップブチル $2^{6)}$, フラザスルフロン $3^{7)}$, クロルフルアズロ ン $4^{8)}$ ，フルアジナム $5^{9)}$ を創製，上市している（Fig. 2)。こ れらはいずれもピリジン環の $\beta$ 位に $\mathrm{CF}_{3}$ 基を有し, さらに 2 位で他の官能基とへテロ原子を介して結合している.

我々は新たな生理活性化合物の探索を進めるにあたり, これまでに当社で十分な研究がされていない「 $\mathrm{CF}_{3}$ 基を $\beta$ 位 以外に持ち，ピリジン環から炭素鎖で新たな置換基と結合 する」 $\mathrm{CF}_{3}$-ピリジン化合物に着目した。これらの条件を満 足する誘導体を集中的に検討したところ，ハスモンヨトウ (Spodoptera litura) やナミハダニ（Tetranychus urticae）に 対しては $800 \mathrm{ppm}$ 処理であっても十分な殺虫効果を示さない が, モモアカアブラムシ（Myzus persicae）に対し $12.5 \mathrm{ppm}$
の $\mathrm{LC}_{90}$ 值を示す N-2-(ピリジルメチル)-4-(トリフルオロメ チル）二コチンアミド6を見出した（Fig. 3).また，6は高 い植物浸透移行性を示すことも見出されたことから, 興味あ る特性を有する6をリード化合物として誘導体合成を進める こととした。

なお，構造最適化のために誘導体を合成するに当たり，鍵 となる中間体の 4-(トリフルオロメチル) ニコチン酸7は, 公知の文献に従い 4,4,4-トリフルオロアセト酢酸エチルと2シアノアセトアミドから得られる，2,6-ジヒドロキシ-4-(ト リフルオロメチル）二コチノニトリル $\mathbf{8}^{10)}$ を経由して合成し た.アミド誘導体への変換は 7 を塩化チオニルで酸クロリド に変換したあと, 対応するアミンと反応させる, 簡便な方法 で可能であった (Fig. 4) ${ }^{11)}$.

\section{2. フロニカミドの創製}

リード化合物 6 のアミドの $\mathrm{N}$ の置換基の 2-ピリジルメチル 基を3-ピリジルメチル基, および4-ピリジルメチル基へ変 換した化合物では，モモアカアブラムシに対する殺虫効果 は大きく低下した。さらに，2-ピリジルメチル基からベンジ ル基へ変換した誘導体について検討したが，パラ位に $\mathrm{CF}_{3}$ 基 が置換した場合には6と同等の効果が認められたものの，他 
の誘導体では十分な効果は認められなかった（Fig. 5)。続い て6のニコチノイル側 4 位の置換基変換を行ったが，いずれ も殺虫活性は消失していた。さらに4 位の $\mathrm{CF}_{3}$ 基をピリジン 環の $\alpha$ 位に置換した $2-\mathrm{CF}_{3}, 6-\mathrm{CF}_{3}$ 体を合成したが，十分な活 性は認められなかった（Fig. 6). 次なる展開として，6のア ミド部分のピリジン環を除き $N$-アルキルアミド誘導体への 変換を試みたところ，N-メチルアミドはモモアカアブラム シに対し $3.1 \mathrm{ppm} の \mathrm{LC}_{90}$ 值を示した。 また $N$-エチルアミド では6と同程度の効果であったが，N-n-ブチル基では活性が 低下することが判明した．N-アルキルアミドへの変換で活 性が向上したことからメチル基への置換基導入による高活性 化を目指し種々検討を行った。シアノ基を導入したところメ チル体と同様の高活性であったが，CN三重結合をCC三重 結合に変換したプロパルギル体では活性は低下した。またシ アノ基をメトキシカルボニル基やアミノカルボニル基へ変換 した場合も殺虫活性は低下した，興味深いことに，シアノ基 からチオアミド基への変換は 6 と同等の効果を示した（Fig. 7).

これらの検討の中で見出した高活性化合物について，各種 殺虫活性評価試験を行い，アミド部分にシアノメチル基を導 入した化合物，フロニカミド $\mathbf{1}$ を開発薬剤として選抜した ${ }^{3)}$.<smiles>[R]CNC(=O)c1cnccc1C(F)(F)F</smiles>

\section{$\mathrm{R}_{1}: 2-\mathrm{Py}, 4-\mathrm{CF}_{3} \mathrm{Ph}>3-\mathrm{CF}_{3} \mathrm{Ph}>4-\mathrm{Py}, 2-\mathrm{CF}_{3} \mathrm{Ph}>3-\mathrm{Py}$}

Fig. 5. Structure-activity relationship of $N$-arylmethyl derivatives against Myzus persicae.

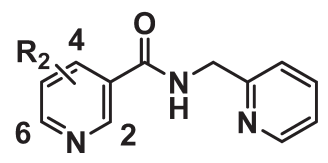

\section{$\mathrm{R}_{2}: 4-\mathrm{CF}_{3} \gg 2-\mathrm{CF}_{3} \gg 6-\mathrm{CF}_{3}, 4-\mathrm{H}, 4-\mathrm{MeO}, 4-\mathrm{F}_{3} \mathrm{CCH}_{2} \mathrm{O}$}

Fig. 6. Structure-activity relationship of substituted nicotinoyl derivatives against Myzus persicae.

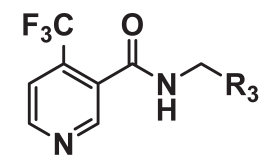

\section{$\mathrm{R}_{3}: \mathrm{H}, \mathrm{CN}, \mathrm{CSNH}_{2}>\mathrm{Me},-\mathrm{C} \equiv \mathrm{CH}>\mathrm{CO}_{2} \mathrm{Me}, \mathrm{CONH}_{2}, n-\mathrm{Pr}$}

Fig. 7. Structure-activity relationship of $N$-substituted methyl derivatives against Myzus persicae.

\section{2. 名称と性状}

一 般 名：フロニカミド (flonicamid)

商品名：ウララ ${ }^{\mathrm{TM}}$, Teppeki $^{\mathrm{TM}}$, Mainman $^{\mathrm{TM}}$, Carbine $^{\mathrm{TM}}$, Turbine $^{\mathrm{TM}}$, Beleaf $^{\mathrm{TM}}$, Aria $^{\mathrm{TM}}$

試 験 名: IKI-220

CAS 番号 : 158062-67-0

IUPAC名 : N-cyanomethyl-4-(trifluoromethyl)nicotinamide 分子式: $\mathrm{C}_{9} \mathrm{H}_{6} \mathrm{~F}_{3} \mathrm{~N}_{3} \mathrm{O}$

Table 1. Insecticidal spectrum of flonicamid in the laboratory

\begin{tabular}{lllc}
\hline Order & \multicolumn{1}{c}{ Scientific name } & Stage $^{\mathrm{a})}$ & $\begin{array}{c}\mathrm{EC}_{50}^{\mathrm{b})} \\
(\mathrm{mg} \text { a.i./L) }\end{array}$ \\
\hline Hemiptera & Myzus persicae & L1 & 0.8 \\
& Aphis gossypii & L1 & 0.4 \\
& Rhopalosiphum padi & All stages & 0.8 \\
& Schizaphis graminum & All stages & 0.8 \\
& Sitobion avenae & All stages & 1.5 \\
Lepidoptera & Lipaphis erysimi & All stages & 2.1 \\
Coleoptera & Aulacophora femoralis & A & $>800$ \\
Diptera & Musca domestica & A & $>800$ \\
Acarina & Tetranychus urticae & A & $>800$ \\
\hline
\end{tabular}

${ }^{a)}$ L1, L2 and A indicate first and second instar larva and adult, respectively. ${ }^{\text {b) }}$ Mortality was assessed 2 to 5 days after treatment in each evaluation method.

Table 2. Major insect pests controlled by flonicamid besides aphids ${ }^{\text {a) }}$

\begin{tabular}{cll}
\hline Order & \multicolumn{1}{c}{ Scientific name } & \multicolumn{1}{c}{ Crop } \\
\hline Hemiptera & Trialeurodes vaporariorum & Vegetable \\
& Nilaparvata lugens & Rice \\
& Sogatella furcifera & Rice \\
& Empoasca onukii & Tea \\
& Amrasca biguttula & Cotton \\
& Bactericera cockerelli & Potato \\
& Arboridia apicalis & Grape \\
& Eysarcoris aeneus & Rice \\
& Cletus punctiger & Rice \\
& Lygus lineolaris & Cotton \\
& Lygus hesperus & Cotton \\
Scirotothrips dorsalis & Tea \\
& Thrips tabaci & Green onion \\
& Frankliniella occidentalis & Vegetable \\
\hline
\end{tabular}

\footnotetext{
${ }^{a)}$ Listed pests are controlled by flonicamid at the level of more than $80 \%$ by foliar spray below $300 \mathrm{~g}$ a.i./ha under field condition.
} 
分子 量: 229.16

外観：白色固体（粉末）

融 点: $157.5^{\circ} \mathrm{C}$

水溶解度 $: 5.2 \mathrm{~g} / \mathrm{L}\left(20^{\circ} \mathrm{C}\right)$

オクタノール $/$ 水分配係数 $: \log P_{\mathrm{ow}}=0.3\left(29.8^{\circ} \mathrm{C}\right)$

\section{3. フロニカミドの作用特性}

\section{1. 活性スペクトル}

フロニカミドの各種害虫に対する殺虫効果を Table 1 に示 した.アブラムシ類に対し生育ステージや種の違いにかかわ らず高い活性を示すが，一方，チョウ目，コウチュウ目，八 エ目，ダニ目には活性を示さない。また，種により活性差は あるがポットあるいは圃場試験において，コナジラミ類，キ
ジラミ類, ウンカ類, ヨコバイ類, カメムシ類, アザミウマ 類などの吸汁性害虫に対して防除活性を示すことが確認され ている $\left(\right.$ Table 2) ${ }^{2,12)}$.

\section{2. 吸汁阻害活性}

フロニカミドはアブラムシに対して処理後 0.5 時間以内 に強い吸汁阻害活性を示し，その作用はアブラムシが死亡 するまで継続することから，本剂のアブラムシに対する殺 虫作用は餓死によるものと推定される.さらに電気的測定 （EMIF）法を用いてのモモアカアブラムシの吸汁行動解析 結果から，フロニカミドを処理されたアブラムシでは口吻を 植物に当てる行動は観察されるものの，その時間は短く，唾 液吐出が強く阻害され，それに続く吸汁が完全に抑制されて
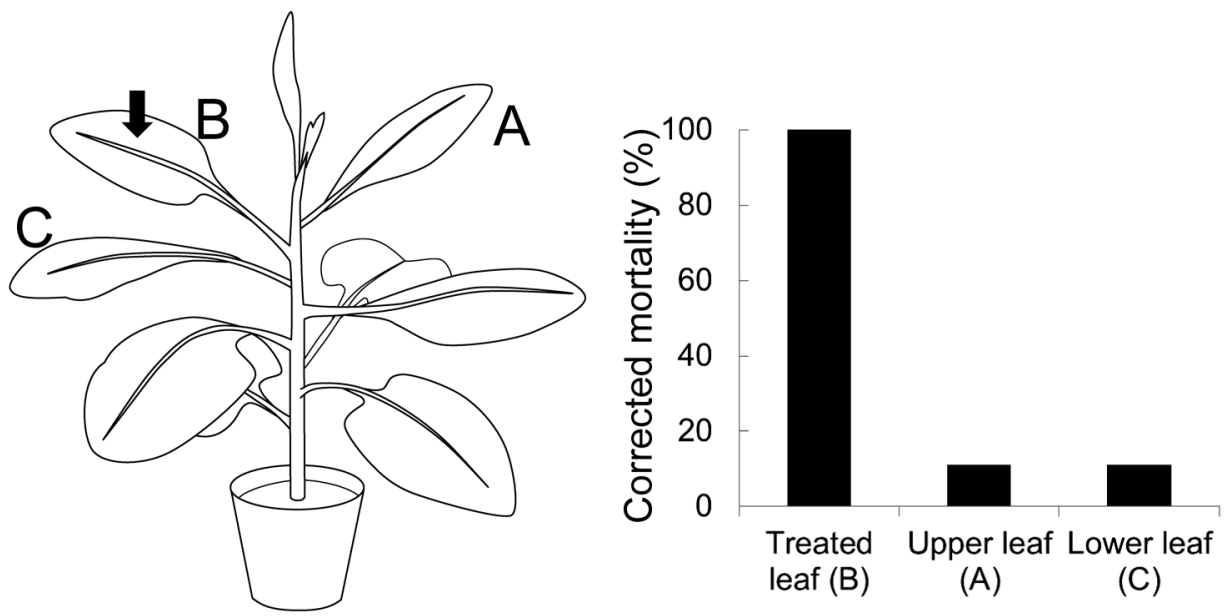

Fig. 8. Efficacy of flonicamid at upper and lower leaf position against Myzus persicae by a drop application on the middle leaf position of potted eggplant. One milliliter of flonicamid $100 \mathrm{ppm}$ solution was deposited on the adaxial side of position (B). Ten second-instar nymphs of Myzus persicae were placed on the abaxial side of postion (A), (B) and (C) at one day after the treatment. Mortality was assessed 5 days after infestation.
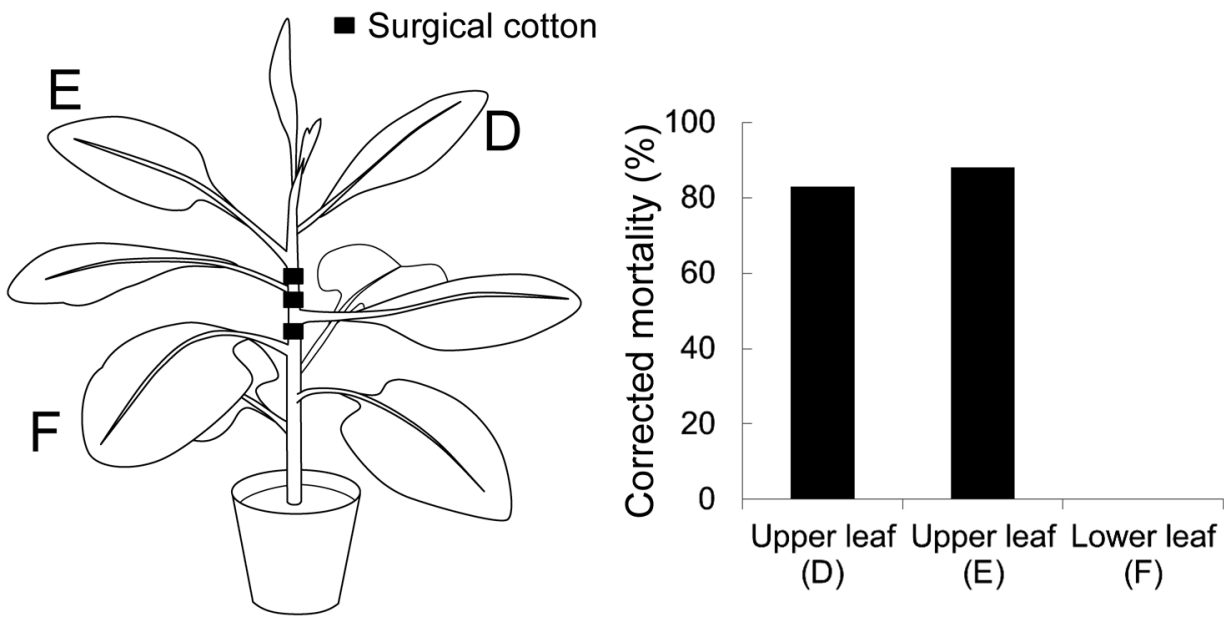

Fig. 9. Efficacy of flonicamid at different leaf position against Myzus persicae by drop applications on stem of potted eggplant. One milliliter of flonicamid $100 \mathrm{ppm}$ solution was deposited on each piece of surgical cotton twisted around stem. Ten second-instar nymphs of Myzus persicae were placed on the abaxial side of postion (D), (E) and (F) at one day after the treatment. Mortality was assessed 5 days after infestation. 
いることが確認された ${ }^{13)}$.

\section{3. 植物体内への浸透移行性}

フロニカミドは, 根部から地上部, 葉表および葉裏から葉 内, さらには処理された茎部より上方の茎葉部に浸透移行す ることが，ポット植えナスでのアブラムシを用いてのバイオ アッセイ（Figs. 8, 9） やトマトでの ${ }^{14} \mathrm{C}$-標識化合物を用いて の実験で確認されている ${ }^{14)}$.

\section{4. 残効性と耐雨性}

フロニカミドは，葉上や葉内で適度の安定性を有してお り, 実用濃度の薬剂が散布された葉面上へのアブラムシ放 虫によるバイオアッセイにおいて 3 週間以上も殺虫活性が持 続した（Fig. 10）。また，処理 3 時間後から，2時間に $40 \mathrm{~mm}$

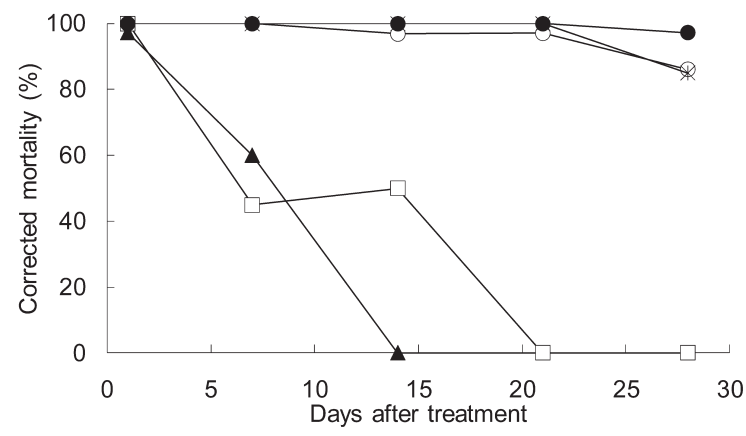

Fig. 10. Lasting activity of flonicamid against Myzus persicae on eggplant. Flonicamid $50 \mathrm{ppm}(\bigcirc)$, Flonicamid $25 \mathrm{ppm}$ $(\bigcirc)$, commercial product A $40 \mathrm{ppm}(*)$, B $75 \mathrm{ppm}(\square)$ and C $125 \mathrm{ppm}(\boldsymbol{\Delta})$ were sprayed to potted eggplants with four leaves maintained. After air-drying, twenty second-instar nymphs were placed on the treated leaves and the treated plants were kept in a greenhouse. Mortality was assessed 7 days later.

Table 3. Rainfastness of flonicamd against Myzus persicae on eggplant $^{\mathrm{a})}$

\begin{tabular}{lccc}
\hline & & \multicolumn{2}{c}{ Corrected mortality (\%) } \\
\cline { 3 - 4 } Product & Dose & $\begin{array}{c}\text { Without artificial } \\
\text { rainfall }\end{array}$ & Artificial rainfall \\
\hline Flonicamid & $50 \mathrm{ppm}$ & 100 & 100 \\
Flonicamid & $25 \mathrm{ppm}$ & 100 & 100 \\
Product A & $40 \mathrm{ppm}$ & 100 & 76 \\
Product B & $75 \mathrm{ppm}$ & 100 & 48 \\
Product C & $125 \mathrm{ppm}$ & 100 & 60
\end{tabular}

a) Eggplants at five-leaf stage planted in pots were sprayed with test solutions $(1000 \mathrm{~L} / \mathrm{ha})$. At $3 \mathrm{hr}$ after treatment, $2 \mathrm{hr}$ of rainfall event was simulated by artificial rainfall generator $(20 \mathrm{~mm} / \mathrm{hr}$, raindrop particle size: $2 \mathrm{~mm}$ ). Twenty second-instar nymphs were placed on the treated leaves at one day after the treatment and the treated plants were kept in a greenhouse. Mortality was assessed 7 days after infestation.
の降雨処理を行っても $100 \%$ の殺虫活性が維持されるとい う，良好な耐雨性を示した（Table 3).

\section{5. 作用機構}

フロニカミドは, 神経系に作用する既存の殺虫剤で認めら れるような全身的な痓攣や麻痺のような中毒症状を示すこと なく, 速効的にアブラムシの吸汁行動を阻害するというユ ニークな作用性を有している。本剂の詳細な作用機作につい ては検討中であるが，アブラムシを対象とした既存の殺虫剂 であるネオニコチノイド剤，有機リン剂，カーバメート剂， 合成ピレスロイド剂及びフィプロニルの結合サイトに作用し ないことが確認されている。 またピメトロジンとの比較で は，ピメトロジンやセロトニンがバッタ腸管の自発的伸縮運 動の伸縮幅や頻度を増強させるのに対し, フロニカミドは全 く影響を及ぼさないことから，両化合物の作用点は異なるも のであると考えている ${ }^{13,15)}$.

\section{6. 各地から採取したワタアブラムシに対する活性}

国内各地のナス科及びウリ科作物から採取したワタアブラ ムシ (Aphis gossypii) 15クローンに対する活性を評価した ところ, 有機リン系, カーバメート系或いは合成ピレスロイ ド系殺虫剤に対して抵抗性を獲得したクローンに対しても， 感受性クローンと同等の高い基礎活性を示し，クローン間で 大きな活性差は認められなかった（Table 4)。 また，圃場試 験でも既存剂への感受性が低下したと思われるアブラムシに 対しても高い防除効果を示すことが確認されている.

\section{7. 天敵に対する安全性}

本剂のアブラムシに対する作用性を考慮し，11評価期間は 原則 5 日間とする，(2)複数の発育ステージへの影響を見るな どの点に注意して評価した。これまでの評価結果から，ナミ テントウなどの甲虫類, カブリダニ類, 寄生蜂類, 八ナカメ ムシ類, など各種天敵類に対して高い安全性を有することが 判明している（Table 5)。このことからフロニカミドはIPM に適合した殺虫剤として有効であると言える ${ }^{4)}$.

\section{4. フロニカミドの安全性}

フロニカミド原体のラットに対する急性経口毒性試験の結 果, $\mathrm{LD}_{50}$ 值は, 雄 $884 \mathrm{mg} / \mathrm{kg}$, 雌 $1768 \mathrm{mg} / \mathrm{kg}$ であり, 急性 経皮毒性試験では雌雄何れも $\mathrm{LD}_{50}$ 值は $5000 \mathrm{mg} / \mathrm{kg}$ 以上，急 性吸入毒性試験では, 雌雄ともに $\mathrm{LC}_{50}$ 值は $4.9 \mathrm{mg} / \mathrm{L}$ 以上と いう高い安全性を示した。

環境生物への安全性評価については，魚類，水生甲殼類， 藻類，鳥類の何れに対しても毒性は弱く，本剂の農薬登録で 規定された使用方法に従って使用すれば環境に悪影響を及ぼ すことなく使用できると考えられる（Table 6）. 
Table 4. Insecticidal activity of flonicamid against various clones of Aphis gossypii

\begin{tabular}{|c|c|c|c|c|c|c|c|}
\hline \multirow{2}{*}{$\begin{array}{c}\text { Population } \\
\text { number }\end{array}$} & \multirow{2}{*}{$\begin{array}{l}\text { Location of } \\
\text { collection }\end{array}$} & \multirow{2}{*}{ Host plant } & \multirow{2}{*}{ Year } & \multicolumn{4}{|c|}{$\mathrm{LC}_{90}$ value, $\mathrm{mg}$ a.i./L } \\
\hline & & & & Flonicamid & Ethiofencarb & Oxydeprofos & Permethrin \\
\hline GSM & Gifu & Eggplant & 1987 & 3.1 & 500 & 450 & 1 \\
\hline GSM2 & Shimane & Eggplant & 1988 & 0.8 & 5 & 4.5 & 1 \\
\hline $92-18$ & Aomori & Eggplant & 1992 & 3.1 & 500 & $>450$ & 1 \\
\hline WK-9306 & Shiga & Eggplant & 1993 & 0.8 & - & - & 1 \\
\hline WK-9407 & Shiga & Eggplant & 1994 & 3.1 & 500 & 450 & $>100$ \\
\hline GMP & Ibaragi & Melon & 1978 & 0.8 & 50 & 450 & 1 \\
\hline $\mathrm{C}-7$ & Kyoto & Cucumber & 1991 & 3.1 & 5 & 45 & 1 \\
\hline $90-\mathrm{J}$ & Shimane & Melon & 1990 & 0.8 & 500 & 450 & 1 \\
\hline $91-2$ & Shimane & Melon & 1991 & 0.8 & 500 & 450 & 1 \\
\hline $92-19$ & Aomori & Calabash & 1992 & 0.8 & 500 & 450 & 1 \\
\hline 01-SM-E & Shiga & Eggplant & 2001 & 3.1 & 50 & 450 & 1 \\
\hline 01-SY-E & Shiga & Eggplant & 2001 & 3.1 & 500 & 450 & 100 \\
\hline 01-H-PU & Hokkaido & Pumpkin & 2001 & 0.8 & 5 & 45 & 1 \\
\hline 01-H-PO & Hokkaido & Potato & 2001 & 3.1 & 500 & 450 & $>100$ \\
\hline 01-H-C & Hokkaido & Cucumber & 2001 & 3.1 & 500 & 450 & $>100$ \\
\hline
\end{tabular}

Table 5. Effect of flonicamid on natural enemies

\begin{tabular}{|c|c|c|c|c|}
\hline Scientific name & Stage ${ }^{a)}$ & $\begin{array}{c}\text { Test } \\
\text { method }^{\text {b) }}\end{array}$ & $\begin{array}{l}\text { Assessment } \\
\text { timing }^{c)}\end{array}$ & $\begin{array}{l}\text { Corrected } \\
\% \text { control }^{\text {d) }}\end{array}$ \\
\hline \multirow[t]{4}{*}{ Orius strigicollis } & A & SP & 5 & - \\
\hline & A & SN & 5 & - \\
\hline & $\mathrm{L}$ & SP & 7 & - \\
\hline & $\mathrm{E}$ & SN & 5 & - \\
\hline \multirow[t]{3}{*}{ Harmonia axyridis } & A & SP & 5 & - \\
\hline & $\mathrm{L}$ & SP & 5 & - \\
\hline & $\mathrm{E}$ & SP & 5 & - \\
\hline Dacnusa sibirica & A & SP & 5 & - \\
\hline \multirow[t]{2}{*}{ Diglyphus isaea } & A & SP & 5 & - \\
\hline & $\mathrm{L}$ & SNP & 14 & - \\
\hline \multirow[t]{2}{*}{ Encarsia formosa } & A & SP & 5 & - \\
\hline & $\mathrm{P}$ & SP & 10 & - \\
\hline \multirow[t]{2}{*}{ Aphidius colemani } & $\mathrm{P}$ & SN & 7 & - \\
\hline & A & SN & 5 & - \\
\hline \multirow[t]{3}{*}{ Amblyseius cucumeris } & A & SP & 5 & - \\
\hline & A & SN & 5 & - \\
\hline & $\mathrm{E}$ & SNP & 2 & - \\
\hline \multirow[t]{2}{*}{ Amblyseius swirskii } & A & SNP & 5 & - \\
\hline & $\mathrm{L}$ & SNP & 5 & - \\
\hline \multirow[t]{3}{*}{ Phytoseiulus persimilis } & A & SP & 5 & - \\
\hline & A & SN & 5 & - \\
\hline & $\mathrm{E}$ & $\mathrm{SN}$ & 2 & - \\
\hline
\end{tabular}

${ }^{\text {a) }} \mathrm{E}, \mathrm{L}, \mathrm{P}$ and $\mathrm{A}$ indicate egg, larva, pupa and adult, respectively. ${ }^{b)}$ Flonicamid $100 \mathrm{ppm}$ solution was sprayed to only prey (SP), only natural enemies (SN) or both of prey and natural enemies (SNP). ${ }^{c)}$ Days after treatment. ${ }^{\mathrm{d})}$ Corrected \% Control: - shows less than $30 \%$.
Table 6. Toxicological and ecotoxicological profile of flonicamid technical

\begin{tabular}{|c|c|c|}
\hline Study & Organism & Result \\
\hline Acute oral & Rat (male, female) & $\mathrm{LD}_{50}: 884 \mathrm{mg} / \mathrm{kg}, 1768 \mathrm{mg} / \mathrm{kg}$ \\
\hline Acute dermal & Rat (male, female) & $\mathrm{LD}_{50}>5000 \mathrm{mg} / \mathrm{kg}$ \\
\hline Acute inhalation & Rat (male, female) & $\mathrm{LC}_{50}>4.9 \mathrm{mg} / \mathrm{L}$ \\
\hline Eye irritation & Rabbit & Slight-irritant \\
\hline Skin irritation & Rabbit & \\
\hline Skin sensitization & Guinea pig & \\
\hline \multirow[t]{3}{*}{ Aquatic toxicity } & Carp & $\mathrm{LC}_{50}>100 \mathrm{mg} / \mathrm{L}$ \\
\hline & Daphnia magna & $\mathrm{EC}_{50}>100 \mathrm{mg} / \mathrm{L}$ \\
\hline & $\begin{array}{l}\text { Selenastrum } \\
\text { capricornutum }\end{array}$ & $\mathrm{E}_{\mathrm{r}} \mathrm{C}_{50}(0-72 \mathrm{hr})>100 \mathrm{mg} / \mathrm{L}$ \\
\hline Bird toxicity & Bobwhite quail & $\mathrm{LD}_{50}>2000 \mathrm{mg} / \mathrm{kg}$ \\
\hline & お わ り & \\
\hline \multicolumn{3}{|c|}{$\begin{array}{l}\text { 本研究では, オリジナル骨格をもつ新規殺虫剂を創製する } \\
\text { ため, 基礎的な殺虫活性に加えて, 薬剂を状投与した作用特性に着目してリード化合物を選定し, その毒 } \\
\text { 最適化研究により, フロニカミ後の } \\
\text { 開始当時は, ネオニコチノイド剂の開発研究が活発に行われ } \\
\text { ている時期であり, 殺虫スヘクトラムの狭い本系統化合物 } \\
\text { が, 開発するに值する市場性を有するのかなどの議論があっ } \\
\text { た. 様々な困難を乗り越えて, 発明から } 20 \text { 年, 上市から } 9 \\
\text { 年あまりが経過した現在, 消費者の安全志向, IPM, 害虫抵 } \\
\text { 抗性管理の重要性が大きく認識される中で, ユニークな特性 }\end{array}$} \\
\hline
\end{tabular}


を持つフロニカミドが世界の作物保護ならびに農業生産へ今

後も貢献し続けることを願っている.

最後に, フロニカミドの開発・商業化にあたり多大なご指 導, ご協力を賜りました国公立試験場, 社団法人日本植物防 疫協会, 財団法人残留農薬研究所, 及び独立行政法人農業・ 食品産業技術総合研究機構の先生方に厚く御礼申し上げま す。また，本剂の研究開発に携わった弊社関係者の方々にも 心から感謝申し上げます。

\section{引用 文 献}

1) M. Morita, T. Ueda, T. Yoneda, T. Koyanagi, S. Murai and N. Matsuo: Proc. Brighton Crop Prot. Conf.-Pests and Diseases, 59-65, (2000).

2) 森田雅之 : 第 24 回農薬生物活性研究会シンポジウム講演要旨集, p. 9, 2007.

3）米田哲夫, 芳賀隆弘：ファインケミカル 38, 21-27 (2009).

4) 森田雅之, 山口晃一, 坂下信行: 日本応用動物昆虫学会第 48 回 大会講演要旨集, p. 92, 2004.

5) 山口晃一, 今井 修, 平野耕治: 日本応用動物昆虫学会第51回 大会講演要旨集, p. 177, 2007.

6）西山隆三, 芳賀隆弘, 坂下信行 (石原産業)：特公昭 58-40947 (1983).

7）木村史雄, 芳賀隆弘, 坂下信行, 本多千元, 林 弘仁, 関 敏男, 南田幸二（石原産業）：特公平6-60173 (1994).

8) 西山隆三, 藤川敢市, 土岐忠昭, 那須陸男 (石原産業)：特公昭 57-53786 (1982).

9) 西山隆三, 藤川敢市, 芳賀隆弘, 土岐忠昭, 長谷邦昭, 今井 修 (石原産業)：特公昭60-52146 (1985).

10) S. Portnoy: J. Org. Chem. 30, 3377-3380 (1965).
11）土岐忠昭, 小柳 徹, 岡田 宏, 森田雅之, 米田哲夫, 鍵本千晴 (石原産業)：日本特許第2994182号 (1999).

12) 今井 修, 加嶋崇之, 森田雅之 : 日本応用動物昆虫学会第 49 回 大会講演要旨集, p. 85, 2005.

13) M. Morita, T. Ueda, T. Yoneda, T. Koyanagi and T. Haga: Pest Manag. Sci. 63, 969-973 (2007).

14）寛座俊孝, 多田康臣, 酒井綾子, 加藤康之：日本農薬学会第 31 回大会講演要旨集, p. 91, 2006.

15) H. Kayser, L. Kaufmann, F. Schürmann and P. Harrewijn: Proc. Brighton Crop Prot. Conf.-Pest and Diseases, 737-742 (1994).

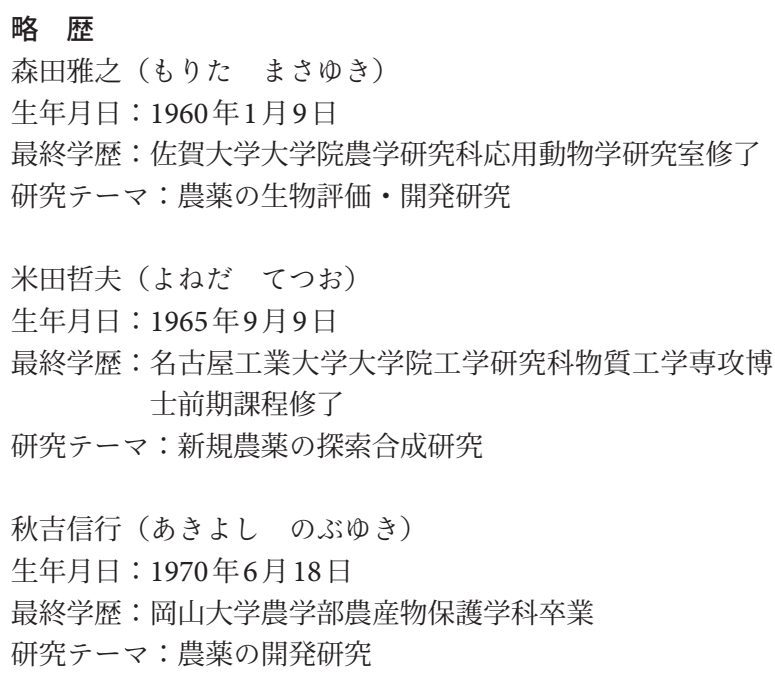

